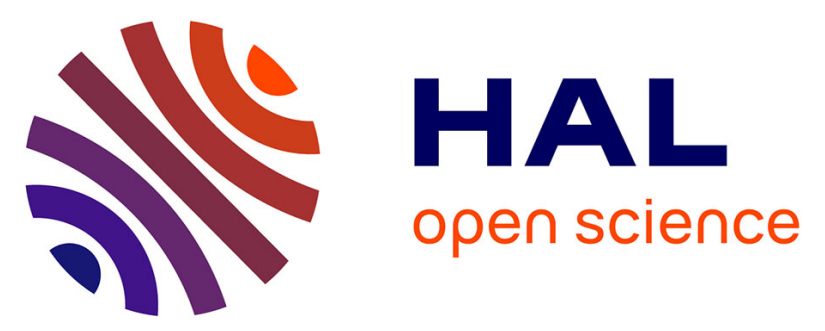

\title{
1-Ethyl-3-methylimidazolium tartrate chiral ionic liquids: preparation, characterization and opportunities thereof
}

Tessa Castellan, Claire Cuyamendous, Juliette Fitremann, Jean-Marie Galano, Camille Oger, Thierry Durand, F. Guillen, Yves Génisson

\section{To cite this version:}

Tessa Castellan, Claire Cuyamendous, Juliette Fitremann, Jean-Marie Galano, Camille Oger, et al.. 1-Ethyl-3-methylimidazolium tartrate chiral ionic liquids: preparation, characterization and opportunities thereof. New Journal of Chemistry, 2018, 42 (23), pp.18739-18748. 10.1039/C8NJ03175D . hal-02059223

\section{HAL Id: hal-02059223 \\ https://hal.science/hal-02059223}

Submitted on 3 Jun 2021

HAL is a multi-disciplinary open access archive for the deposit and dissemination of scientific research documents, whether they are published or not. The documents may come from teaching and research institutions in France or abroad, or from public or private research centers.
L'archive ouverte pluridisciplinaire HAL, est destinée au dépôt et à la diffusion de documents scientifiques de niveau recherche, publiés ou non, émanant des établissements d'enseignement et de recherche français ou étrangers, des laboratoires publics ou privés. 


\title{
1-Ethyl-3-methylimidazolium tartrate chiral ionic liquids: preparation, characterization and opportunities thereof $\dagger$
}

\author{
Tessa Castellan, ${ }^{a}$ Claire Cuyamendous, ${ }^{b}$ Juliette Fitremann, ${ }^{c}$ Jean-Marie Galano, ${ }^{b}$ \\ Camille Oger, ${ }^{b}$ Thierry Durand, ${ }^{b}$ Frédéric Guillen ${ }^{a}$ and Yves Génisson $\quad$ *a \\ A unified acid/base synthetic access to tartrate-based chiral ionic liquids relying on the generation \\ of cation hydroxide salts with $\mathrm{AgOH}$ was challenged with the preparation of sensitive 1-ethyl-3- \\ methylimidazolium derivatives. Systematic variation of the starting tartaric acid stoichiometry and \\ configuration led to eight stereoisomeric 1-ethyl-3-methylimidazolium hydrogen tartrate or di-(1-ethyl- \\ 3-methylimidazolium)tartrate entities. These salts were all characterised as proper ionic liquids. An \\ unprecedented influence of the configuration $((2 S, 3 S)$, or $(2 R, 3 R)$ vs. racemic or meso) on dynamic \\ viscosity was observed. The relevance of such tartrate salts as task-specific ionic liquids was demonstrated \\ in a synthetically useful base-promoted intramolecular cyclisation of a $C_{2}$-symmetrical bis-epoxide en \\ route to the total synthesis of phytofuran metabolites.
}

\section{Introduction}

Chiral ionic liquids (CILs) represent an appealing class of ionic liquids (ILs) combining highly diverse structural features ${ }^{1}$ with multiple fields of applications. They have for instance been used in physical and materials chemistry, ${ }^{2}$ analytical and separative chemistry, ${ }^{3}$ catalysis and synthetic chemistry. ${ }^{4}$ Among CILs, bio-sourced derivatives are intended to further address the issue of eco-compatibility and sustainability. ${ }^{5}$ Naturally abundant and renewable precursors obtained from the chiral pool, such as amino or hydroxy acids, carbohydrates and alkaloids, were used to generate either the cation, the anion, or both cation and anion, of such "bio-ionic liquids". ${ }^{6}$ Direct use of biopolymers such as proteins and polysaccharides has also been explored. ${ }^{5}$

In this context, tartaric acid holds a particular position as an omnipresent source of inspiration in the long-lasting quest for chirality. The field of alternative reaction media naturally came to exploit the potential of tartaric acid as a chiral precursor. ${ }^{7}$ Several deep eutectic solvents combining tartaric acid with

\footnotetext{
${ }^{a}$ SPCMIB Laboratory, UMR CNRS 5068, Université Paul Sabatier, 118 route de Narbonne, 31062 Cedex 9, Toulouse, France.E-mail: genisson@chimie.ups-tlse.fr

${ }^{b}$ Institut des Biomolécules Max Mousseron, IBMM, Université de Montpellier, CNRS, ENSCM, Faculté de Pharmacie 15 Av. Ch. Flahault BP 14491 F-34093 Montpellier Cedex 05, France

${ }^{c}$ IMRCP Laboratory, Université de Toulouse, CNRS UMR 5623, Université Toulouse III - Paul Sabatier, 118 route de Narbonne, 31062 Cedex 9, Toulouse, France $\dagger$ Electronic supplementary information (ESI) available: ${ }^{1} \mathrm{H}$ and ${ }^{13} \mathrm{C}$ NMR and viscosity measurement data. See DOI: 10.1039/c8nj03175d
}

achiral components were for instance reported for synthetic applications. $^{8}$

Since the first report of tetrabutylammonium tartrates by Maschmeyer and colleague in 2006, ${ }^{9}$ tartrate-based CILs have attracted a constant attention, finding applications in various areas ranging from environmental sciences to physico-, nanoand pharmaco-chemistry as well as organometallic catalysis and organic synthesis.

Yuan and colleague described a 1-butyl-3-methylimidazolium hydrogen tartrate as an IL with buffering properties. ${ }^{10}$ In the course of a study on stereoselective fluorescence quenching, Petrich and colleague reported a bis(tetrabutylphosphonium)tartrate. ${ }^{11}$ Jing and colleague explored the use of several bis(alkylpyridinium)tartrates as chiral additives for asymmetric cycloaddition of $\mathrm{CO}_{2}$ to epoxides. ${ }^{12} \mathrm{Bis}($ tetrabutylammonium)tartrate proved useful in the development of IL-assisted synthesis of $\mathrm{ZnO} / \mathrm{Sn}_{2} \mathrm{O}^{13}$ and $\mathrm{BaCO}_{3}$ nanostructures. ${ }^{14}$ Mandal and colleague employed a choline tartrate in an IL-enhanced biodegradation of azo dyes. ${ }^{15}$ An enantioselective liquid-liquid extraction process was devised based on bis(tetrabutylphosphonium)tartrate CIL. ${ }^{16}$ A commercial 1-octyl-3-methylimidazolium hydrogen tartrate was proposed as a surface active IL able to solubilize pesticides in water. ${ }^{17}$ Tartrate-based ILs were prepared from the antifungal drug ketoconazole to try to improve the compound's water solubility. ${ }^{18}$ Bouquillon and colleague used both tetrabutylammonium and tetrabutylphosphonium hydrogen tartrates as a co-solvent for aqueous Pd-catalysed hydrogenation reactions ${ }^{19}$ or as solvent for a Heck cross-coupling reaction. ${ }^{20}$ Lately, a commercial choline hydrogen 
tartrate CIL was employed in conjunction with a $\mathrm{Zn}$ (II)-based catalyst to enhance the stereoselectivity of a Diels-Alder reaction. ${ }^{21}$ In addition, the protic salt obtained from a lauryl monoester of diacetyl tartrate and $(S)-(-)-\alpha$-methylbenzylamine was recently found to be the first CIL forming micelles and

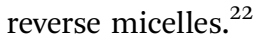

In addition, the potential threat of diverse 1-alkyl-3-methylimidazolium tartrate CILs for aquatic environment was explored by studying their toxicity for the microalgae Scenedesmus obliquus. The strong contribution of the cation alkyl chain length ${ }^{23}$ was shown to override the influence of chirality of the tartrate anion on toxicity, shorter alkyl residues minimizing cell penetration, growth inhibition rates and oxidative stress. ${ }^{24}$

Synthetic access to organic cation-based tartrate salts could appear trivial and these CILs were sometimes employed without proper description. ${ }^{13,14,15,25}$ The relevance of the use of CILs, and a fortiori of tartrate-based entities, is however strongly dependent on their chemical integrity, which, in the absence of any practical purification method, directly relies on their preparation procedure. All the reported syntheses are based on the neutralization of tartaric acid with an organic hydroxide salt. $^{6,9-12,19,20}$ This approach, ${ }^{26}$ popularized by the work of Ohno and colleague, ${ }^{27}$ avoids potential contamination with the halide salts resulting from anion metathesis. However, it raises the issue of the access to the required hydroxide salt. Most of these studies therefore focus on commercially available tetrabutylammonium and tetrabutylphosphonium hydroxide. .,11,19,20 $^{-19}$

The imidazolium hydroxide salts required for the preparation of the corresponding tartrate or hydrogen tartrate ionic liquids have been prepared from the corresponding halide salts by treatment with $\mathrm{NaOH}$ or $\mathrm{KOH}$ in nonpolar organic solvents such as dichloromethane. ${ }^{28}$ This straightforward method has since been widely used for the preparation and isolation of 1,3-dialkylimidazolium hydroxides, among other ammonium hydroxide salts. ${ }^{29}$ However, further studies have shown that, as anticipated by calculations, ${ }^{30}$ the exact nature of the claimed "1,3-dialkylimidazolium hydroxide" species is more akin to an hydrated carbene, due to the acidity of the azolium protons. ${ }^{31}$ These compounds, highly prone to decomposition, can therefore only be isolated as a dilute to moderately concentrated solution in water or protic solvents. The use of an anion exchange resin ${ }^{32}$ represent an elegant alternative that was applied to the preparation of several tartrate-based CILs, ${ }^{6,10}$ avoiding the generation of stoichiometric amounts of undesired halide salts. ${ }^{33}$ Access to these organic hydroxide salts has gained further interest due to the use of 1-butyl-3-methylimidazolium ([BMIM]) hydroxide in catalysis as basic task-specific ionic liquids (TSILs). ${ }^{34}$

\section{Results and discussion}

\section{Optimization of the synthetic approach}

We previously developed a unified route to tartrate-based CILS relying on a practical and general access to organic hydroxide salts (Scheme 1). ${ }^{35}$ This approach relies on the treatment of an

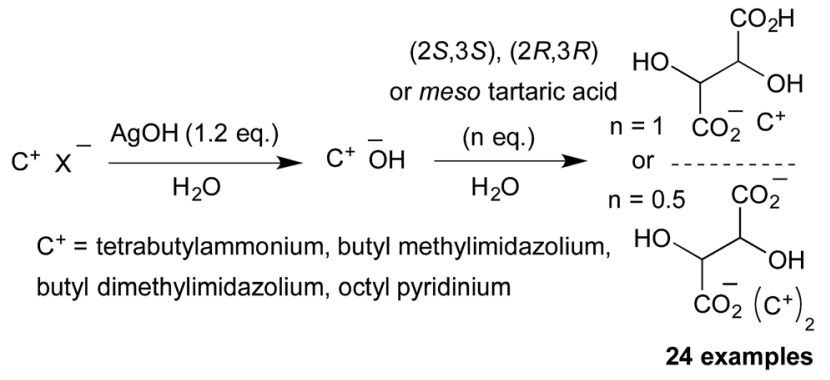

Scheme 1 Unified synthetic access to tartrate-based ILs.

onium halide with the halophilic base $\mathrm{AgOH} .{ }^{26}$ Precipitation of the formed silver halide ensures an irreversible shift of the equilibrium in the course of the anion metathesis. A one pot version of this approach had been mentioned for the preparation of several bis(alkylpyridinium)tartrate CILs. ${ }^{12}$ Due to the high added-value of these hydroxide salts as basic TSILs, we systematically isolated and characterized these entities. Clean aqueous solutions of organic hydroxide salts, exempt from halide salts contamination, were readily obtained from ammonium, pyridinium and imidazolium halide precursors. They were used to prepare 24 different tartrate-based ionic liquids from the $(2 S, 3 S),(2 R, 3 R)$ or meso forms of tartaric acid. ${ }^{35}$

We wished to challenge this general approach with the preparation of demanding 1-ethyl-3-methylimidazolium (EMIM) derivatives. Due to the reduced steric hindrance generated by the ethyl residue, the cation is indeed particularly sensitive to basic conditions. ${ }^{31}$ These entities have, to the best of our knowledge, never been described in the literature. The use of commercial "1-ethyl-3-methylimidazole tartrates" (Shanghai Chengjie Chemical) were only reported in a study on CILmodified Au nanoparticle chiral recognition of amino acids enantiomers $^{36}$ and in the enantiomeric separation of aminoacids by chiral ligand exchange capillary electrophoresis. ${ }^{37}$ Our preliminary work, indicating that EMIM tartrates were, as expected, significantly less viscous than their 1-butyl-3-methylimidazolium counterparts, prompted us to tackle their preparation and characterization. We present here our work along this line.

We started studying the access to the hydroxide precursor. Large scale preparation of dilute aqueous solutions of [EMIM]OH have been reported from [EMIM] $\left[\mathrm{EtSO}_{4}\right]$ by bipolar membrane electrodialysis $^{38}$ or employing an anion exchange resin. ${ }^{39}$ Our first attempts to implement the previously developed procedure using AgOH to generate [EMIM] OH from the corresponding bromide salt in water proved troublesome. Such medium scale reactions (typical concentration $0.3 \mathrm{M}$ ) could easily be run in $\mathrm{D}_{2} \mathrm{O}$, allowing direct NMR monitoring of the transformation and product characterization. Treatment of [EMIM]Br with 1.5 equiv. of AgOH led to the apparition of two distinct imidazolium derivatives in ${ }^{1} \mathrm{H}$ NMR (Fig. 1). The more shielded set of protons could be easily assigned to the silver carbene complex in 2D NMR heteronuclear multiplebond correlation (HMBC) experiments (Fig. 2 left). All protons from the $\mathrm{C} 3 / \mathrm{C} 4$ imidazolium ring as well as the methyl and the 

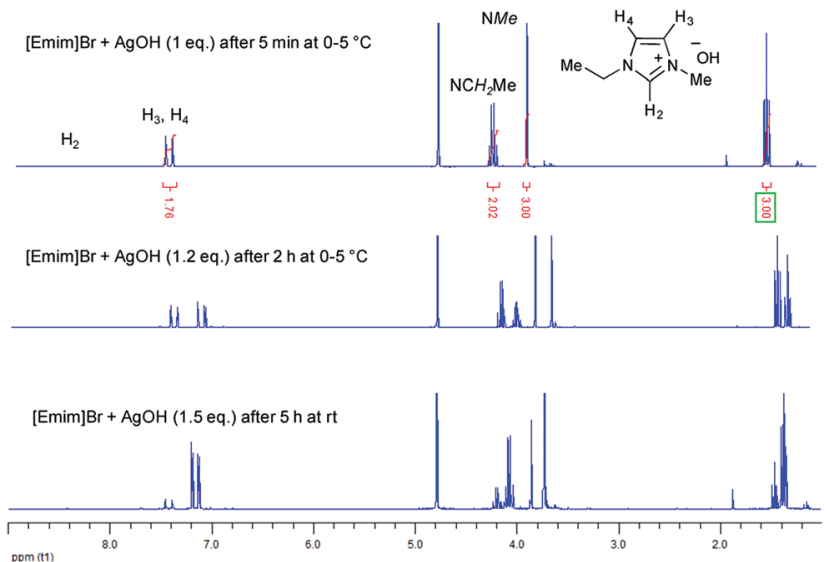

Fig. $1{ }^{1} \mathrm{H}$ NMR spectra $\left(\mathrm{D}_{2} \mathrm{O}, 300 \mathrm{MHz}\right)$ of $[\mathrm{Emim}] \mathrm{Br}+\mathrm{AgOH}(1.5$ equiv. $)$ after $5 \mathrm{~h}$ at RT (bottom), [Emim] Br $+\mathrm{AgOH}$ (1.2 equiv.) after $2 \mathrm{~h}$ at $0-5{ }^{\circ} \mathrm{C}$ (middle) and $[\mathrm{Emim}] \mathrm{Br}+\mathrm{AgOH}$ (1 equiv.) after 5 min at $0-5^{\circ} \mathrm{C}$ (top).

methylene of the ethyl residue indeed displayed a strong ${ }^{3} J$ correlation with a downfield carbon at $179 \mathrm{ppm}$ typical of the carbenic centre.

Optimization of the reaction conditions allowed favouring the formation of the expected [EMIM] OH at the expense of the undesired silver carbene complex. Whereas the use of 1.2 equivalent of $\mathrm{AgOH}$ for $2 \mathrm{~h}$ at $0-5{ }^{\circ} \mathrm{C}$ led to a $1: 1$ mixture of both compounds, further reducing the amount of base (1 equivalent) and the reaction time $(5 \mathrm{~min})$ allowed production of a clean crude mixture. 2D NMR HMBC experiments led to the unambiguous assignment of the structure of [EMIM]OH to this product (Fig. 2 right). In particular, a strong ${ }^{3} J$ correlation with a carbon at $138 \mathrm{ppm}$ was observed for the $\mathrm{C} 3 / \mathrm{C} 4$ imidazolium ring as well as the methyl and the methylene of the ethyl residue.

\section{Preparation}

With this facile and reliable preparation of [EMIM] $\mathrm{OH}$ in hands, we studied the synthesis of the corresponding tartrate salts. Addition of 0.5 or 1.0 equiv. of tartaric acid to the freshly prepared ca. $0.05 \mathrm{M}$ aqueous hydroxide solution led to the expected tartrate or hydrogen tartrate ILs, respectively (Scheme 2).

\section{Physicochemical characterization and properties}

A total of eight tartrate-based ILs were prepared starting from either $(2 S, 3 S),(2 R, 3 R)$, racemic or meso tartaric acid. Analytically pure samples were obtained after gentle drying at RT under ca. $10^{-3}$ mbar for $48 \mathrm{~h}$. Elementary analyses indicated typical water contents comprised between 0.25 and 3.5 molar equivalents, corresponding to $2-15 \%$ in weight. They were characterized by standard methods and gave characteristic trends in accord with our previous report (Table 1). ${ }^{35}$

Typical NMR chemical shifts patterns were observed for the tartrate moieties. Whereas the $\mathrm{CO}$ and $\mathrm{HCOH}$ carbons display typical signals at 176-177 and $74 \mathrm{ppm}$, respectively, in all hydrogen tartrate salts, the same carbons were systematically found shifted downfield to $178-179$ and $75-76 \mathrm{ppm}$ in all tartrate derivatives. On the other hand, the protons carried by the two stereogenic centres of the hydrogen tartrate anions gave a signal around $4.4 \mathrm{ppm}$ that was shifted to around $4.2 \mathrm{ppm}$ in the more electron-rich tartrate salts, the meso derivatives giving a slightly more shielded signal in both cases. ${ }^{9}$

Attenuated total reflectance Fourier transform infrared spectroscopy (ATR-FTIR) analysis showed standard vibrational bands for the $\mathrm{O}-\mathrm{H}, \mathrm{COO}-\mathrm{H}, \mathrm{C}=\mathrm{O}$ and $\mathrm{C}-\mathrm{O}$ bonds. Aromatic $\mathrm{C}-\mathrm{H}$ vibration frequencies in 1,3-dialkyl imidazolium ILs have been assigned and studied in details. ${ }^{40}$ In particular, Li and colleague correlated the lowering of the $\mathrm{C}-2-\mathrm{H}$ stretching frequency in ATR-IR to the electron density of H-bonding with the anion..$^{40} \mathrm{~A}$ frequency of $3105 \mathrm{~cm}^{-1}$ was notably reported for BMIM trifluoroacetate. The assignment of the C-2-H stretching bands of the prepared EMIM ILs can be based on our previous study comparing the C-2-methyl with the C-2-H derivatives. ${ }^{35}$ Frequencies ranging from 3112 (for the H-Tart salts) (Fig. 3) to $3086 \mathrm{~cm}^{-1}$ (for the Tart derivatives) were typically observed, coherent with the strong $\mathrm{H}$-bonding with the tartrate anions.

The thermal stability of the different tartrate-based ILs was assessed by differential thermal analysis (Table 1). Temperatures
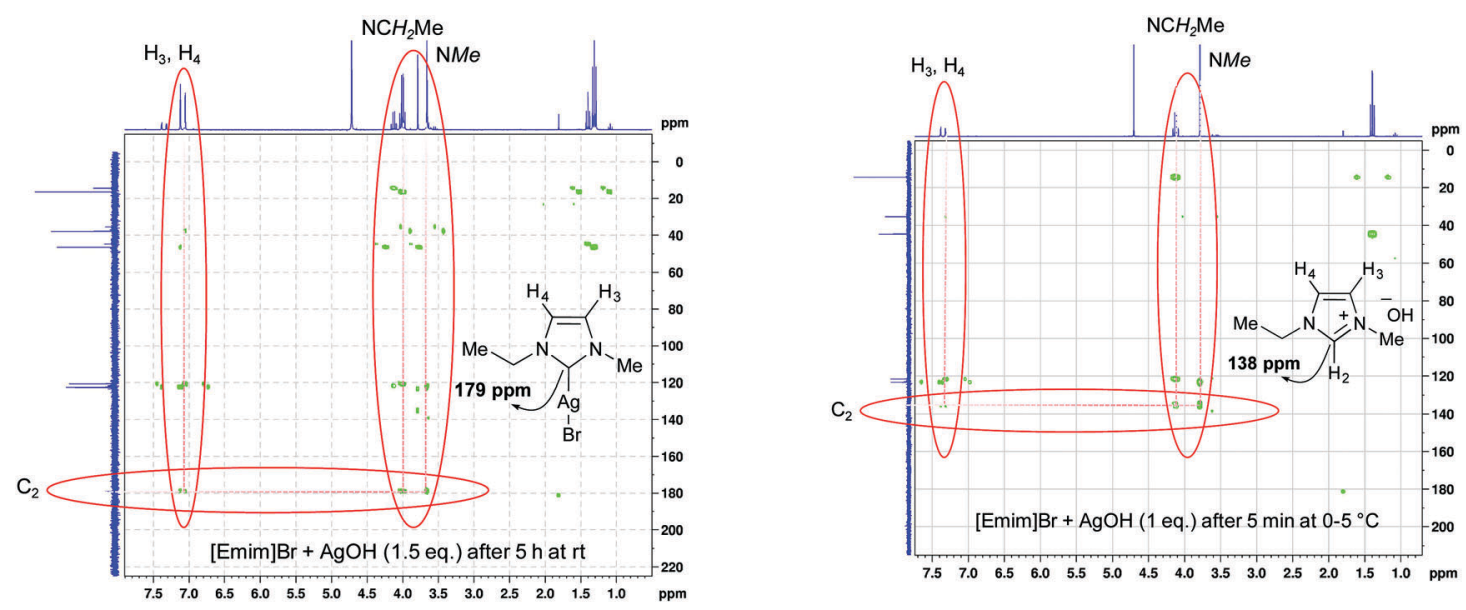

Fig. 2 2D NMR HMBC experiments $\left(\mathrm{D}_{2} \mathrm{O}, 300 \mathrm{MHz}\right)$ of $[\mathrm{Emim}] \mathrm{Br}+\mathrm{AgOH}$ (1.5 equiv.) after $5 \mathrm{~h}$ at $\mathrm{RT}$ (left) and $[\mathrm{Emim}] \mathrm{Br}+\mathrm{AgOH}(1 \mathrm{equiv}$.) after $5 \mathrm{~min}$ at $0-5{ }^{\circ} \mathrm{C}$ (right). 


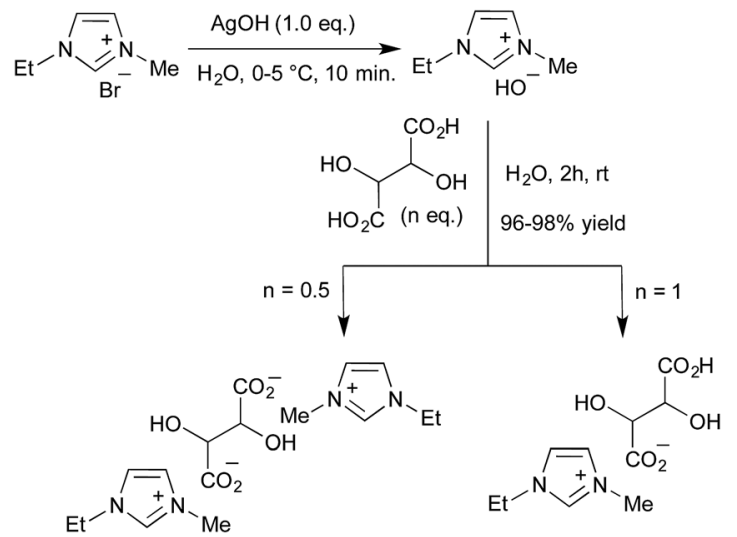

Scheme 2 Synthetic route to EMIM tartrate ILs.

of decomposition ( $T_{\mathrm{d}}$, determined from the onset of weight loss) were found raging from 188 to $200{ }^{\circ} \mathrm{C}$ for the hydrogen tartrates, and from 217 to $240{ }^{\circ} \mathrm{C}$ for the tartrates, lacking of acidic proton, demonstrating an overall appreciable degree of thermal stability.

Differential scanning calorimetry (DSC) was then used to analyse the phase behaviour of the eight tartrate salts. Compounds were found to display only a glass transition $\left(T_{\mathrm{g}}\right.$, expressed as the

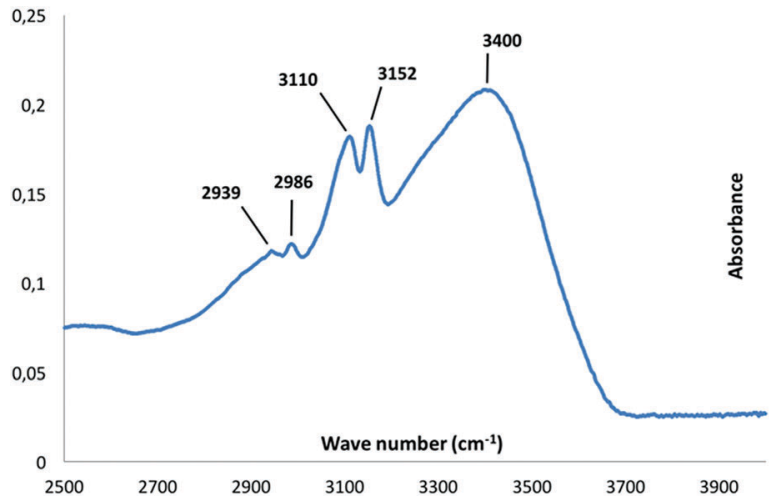

Fig. 3 ATR-IR absorption spectra in the window $2500-4000 \mathrm{~cm}^{-1}$ of [EMIM] $(2 R, 3 R)-\mathrm{HTart}(+)-\mathbf{1 a}$ showing the characteristic $\nu \mathrm{C}-2-\mathrm{H}$ at $3110 \mathrm{~cm}^{-1}$.

inflexion point during the second heating cycle at $5{ }^{\circ} \mathrm{C} \min ^{-1}$ ) at temperatures ranging from -16 to $-52{ }^{\circ} \mathrm{C}$ (Table 1), without any other solid-liquid phase transition, in accord with their designation as room temperature ILs (Fig. 4). As in our previous study, all hydrogen tartrate salts gave $T_{\mathrm{g}}$ values higher that their tartrate analogues, in consistence with their stronger capacity to develop cohesive hydrogen bonds.

Table 1 Selected physicochemical data of EMIM tartrate ILs (only the natural chiral enantiopure (2R,3R)-tartrate series is reported)

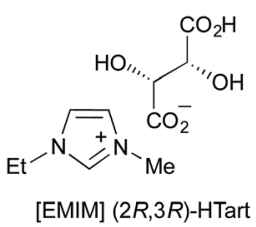

$(+)-1$

Yield: $97 \%$ (viscous oil)

$[\alpha]_{\mathrm{D}}^{20}\left(c 1, \mathrm{H}_{2} \mathrm{O}\right):+11.6$

${ }^{13} \mathrm{C}$ NMR (75 MHz, $\left.\mathrm{CD}_{3} \mathrm{OD}\right), \delta(\mathrm{ppm})$ : $176.50(\mathrm{CO}), 74.03(\mathrm{HCOH})$

${ }^{1} \mathrm{H}$ NMR (300 MHz, $\left.\mathrm{CD}_{3} \mathrm{OD}\right), \delta(\mathrm{ppm}): 4.46$ $(\mathrm{HCOH})$

ATR-IR, $\nu\left(\mathrm{cm}^{-1}\right): 3152(\mathrm{C}-4,5-\mathrm{H}), 3110(\mathrm{C}-2-\mathrm{H})$, 1732 (CO, acid), 1601, 1336 (carboxylate) $T_{\mathrm{d}}\left({ }^{\circ} \mathrm{C}\right): 188 ; T_{\mathrm{g}}\left({ }^{\circ} \mathrm{C}\right):-19$

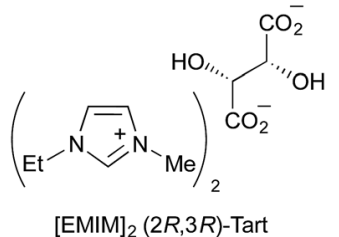

$(+)-2$

Yield: $97 \%$ (viscous oil) $[\alpha]_{\mathrm{D}}^{20}\left(c 1, \mathrm{H}_{2} \mathrm{O}\right):+11.1$

${ }^{13} \mathrm{C}$ NMR (75 MHz, $\left.\mathrm{CD}_{3} \mathrm{OD}\right), \delta(\mathrm{ppm})$ : $179.12(\mathrm{CO}), 75.21(\mathrm{HCOH})$

${ }^{1} \mathrm{H}$ NMR (300 MHz, $\left.\mathrm{CD}_{3} \mathrm{OD}\right), \delta$ (ppm): 4.32 $(\mathrm{HCOH})$

ATR-IR, $\nu\left(\mathrm{cm}^{-1}\right): 3149(\mathrm{C}-4,5-\mathrm{H}), 3102(\mathrm{C}-2-\mathrm{H})$ 1604, 1352 (carboxylate) $T_{\mathrm{d}}\left({ }^{\circ} \mathrm{C}\right): 233, T_{\mathrm{g}}\left({ }^{\circ} \mathrm{C}\right):-54$

Viscosity at $20^{\circ} \mathrm{C}$ (Pa s): 192<smiles></smiles>

Yield: $96 \%$ (viscous oil) $[\alpha]_{\mathrm{D}}^{2 \mathrm{O}}\left(c 1, \mathrm{H}_{2} \mathrm{O}\right)$ :

${ }^{13} \mathrm{C}$ NMR (75 MHz, $\left.\mathrm{CD}_{3} \mathrm{OD}\right), \delta(\mathrm{ppm})$ : 176.31 (CO), $74.35(\mathrm{HCOH})$

${ }^{1} \mathrm{H}$ NMR (300 MHz, $\mathrm{CD}_{3} \mathrm{OD}$ ), $\delta$ (ppm): 4.40 $(\mathrm{HCOH})$

ATR-IR, $\nu\left(\mathrm{cm}^{-1}\right): 3149$ (C-4, 5-H), 3105 (C-2-H), 1731 (CO, acid), 1607, 1355 (carboxylate) $T_{\mathrm{d}}\left({ }^{\circ} \mathrm{C}\right): 200, T_{\mathrm{g}}\left({ }^{\circ} \mathrm{C}\right):-19$

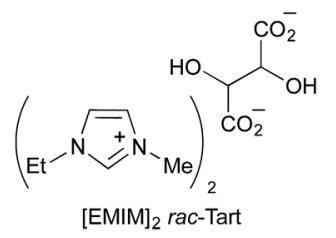

(rac)-2

Yield: 96\% (viscous oil)

$[\alpha]_{\mathrm{D}}^{20}\left(c 1, \mathrm{H}_{2} \mathrm{O}\right): 0$

${ }^{13} \mathrm{C}$ NMR (75 MHz, $\left.\mathrm{CD}_{3} \mathrm{OD}\right), \delta(\mathrm{ppm})$ : 178.95 (CO), $75.16(\mathrm{HCOH})$

${ }^{1} \mathrm{H}$ NMR (300 MHz, $\left.\mathrm{CD}_{3} \mathrm{OD}\right), \delta(\mathrm{ppm}): 4.31$ $(\mathrm{HCOH})$

ATR-IR, $\nu\left(\mathrm{cm}^{-1}\right): 3144(\mathrm{C}-4,5-\mathrm{H}), 3086(\mathrm{C}-2-\mathrm{H})$, 1606, 1347 (carboxylate) $T_{\mathrm{d}}\left({ }^{\circ} \mathrm{C}\right): 240, T_{\mathrm{g}}\left({ }^{\circ} \mathrm{C}\right):-39$ Viscosity at $20^{\circ} \mathrm{C}$ (Pa s): 6<smiles></smiles>

[EMIM] meso-HTart meso-1

Yield: 97\% (wax)

$[\alpha]_{\mathrm{D}}^{20}\left(c 1, \mathrm{H}_{2} \mathrm{O}\right): 0$

${ }^{13} \mathrm{C}$ NMR (75 MHz, $\left.\mathrm{CD}_{3} \mathrm{OD}\right), \delta(\mathrm{ppm})$ :

$177.08(\mathrm{CO}), 74.26(\mathrm{HCOH})$

${ }^{1} \mathrm{H}$ NMR (300 MHz, $\mathrm{CD}_{3} \mathrm{OD}$ ), $\delta$ (ppm): 4.31 $(\mathrm{HCOH})$

, ATR-IR, $\nu\left(\mathrm{cm}^{-1}\right): 3153(\mathrm{C}-4,5-\mathrm{H}), 3112(\mathrm{C}-2-\mathrm{H})$, 1732 (CO, acid), 1608, 1343 (carboxylate) $T_{\mathrm{d}}\left({ }^{\circ} \mathrm{C}\right): 188, T_{\mathrm{g}}\left({ }^{\circ} \mathrm{C}\right):-22$

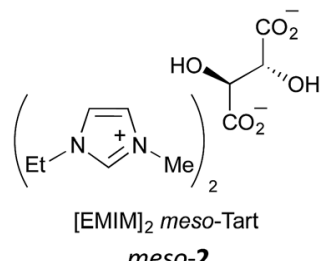

meso-2

Yield: 97\% (viscous oil)

$[\alpha]_{\mathrm{D}}^{20}\left(c 1, \mathrm{H}_{2} \mathrm{O}\right): 0$

${ }^{13} \mathrm{C}$ NMR $\left(75 \mathrm{MHz}, \mathrm{CD}_{3} \mathrm{OD}\right), \delta(\mathrm{ppm}):$ $177.99(\mathrm{CO}), 76.00(\mathrm{HCOH})$

${ }^{1} \mathrm{H}$ NMR (300 MHz, $\left.\mathrm{CD}_{3} \mathrm{OD}\right), \delta(\mathrm{ppm}): 4.14$ $(\mathrm{HCOH})$

ATR-IR, $\nu\left(\mathrm{cm}^{-1}\right): 3145(\mathrm{C}-4,5-\mathrm{H}), 3086(\mathrm{C}-2-\mathrm{H})$ 1606, 1350 (carboxylate)

$T_{\mathrm{d}}\left({ }^{\circ} \mathrm{C}\right): 217, T_{\mathrm{g}}\left({ }^{\circ} \mathrm{C}\right):-53$

Viscosity at $20^{\circ} \mathrm{C}$ (Pa s): 5 


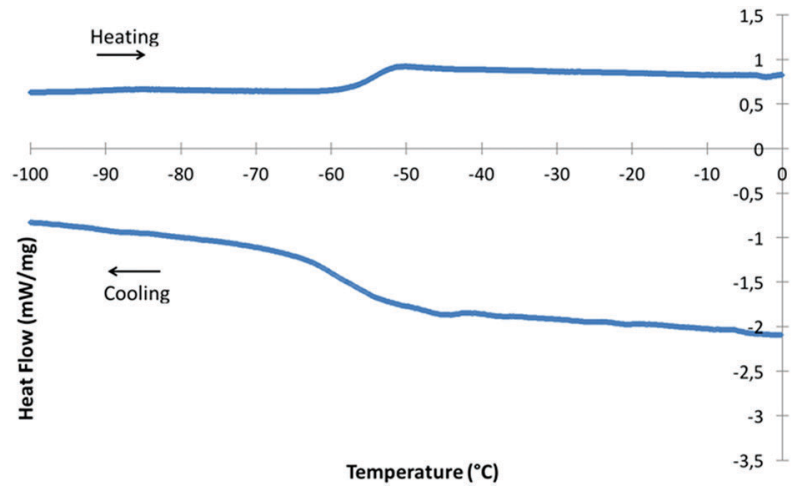

Fig. 4 DSC plot recorded during the second temperature $\left(5^{\circ} \mathrm{C} \mathrm{min}^{-1}\right)$ cycle for $[\mathrm{EMIM}]_{2}(2 R, 3 R)$-Tart $(+)-2 \mathrm{a}$ displaying a $T_{\mathrm{g}}$ of $-54^{\circ} \mathrm{C}$.

Despite of the wide panel of CILs reported to date, it is worth noting that studies addressing the influence of chirality on the relationships between their molecular structure and their macroscopic properties remain scarce and, most importantly, limited to crystalline materials. The group of Luis elegantly studied the impact of the chirality of the cationic component of imidazolium ILs on their physical properties. ${ }^{41}$ The stereoisomeric composition of such salts was shown to influence their melting points, an effect that was correlated to the pattern of hydrogen bond interactions developed between the ions of the corresponding ILs. More recently, Mochida also showed that racemic CILs, based on a branched cationic ruthenium sandwich complex, exhibited a lower melting point than the corresponding enantiopure derivatives, an outcome that was ascribed to the formation of conglomerates. ${ }^{42}$

Having in hands a homogenous series of stereoisomeric ILs deriving from tartaric acid, we decided to explore the influence of the chirality of the tartrate moiety on the rheological properties of four different $[\mathrm{EMIM}]_{2}$ Tart salts. From the macroscopic point of view, a striking difference in viscosity was observed between the ILs deriving from the chiral enantiopure $(2 S, 3 S)$ - or $(2 R, 3 R)$-tartaric acid and the ones obtained from racemic or achiral meso-tartaric acid. The two enantiomeric $(2 S, 3 S)$ - and $(2 R, 3 R)$-tartrate were very viscous liquids that did not flow easily whereas the meso IL and the racemic mixture were fluid. In order to quantify this difference in macroscopic behavior, the dynamic viscosity at $20^{\circ} \mathrm{C}$ was measured by rheology after $48 \mathrm{~h}$ of drying at $c a .10^{-3} \mathrm{mbar}$ (Table 1). A water content of 3 molar equivalent, for both enantiopure $(2 S, 3 S)$ and $(2 R, 3 R)$ samples, and of 2 molar equivalent, for both racemic and meso compounds, was evaluated on the basis of their elementary analyses. Both chiral ILs displayed a viscosity around $200 \mathrm{~Pa}$ s, two order of magnitude higher than that of the achiral IL (meso) or the racemic mixture (around $5 \mathrm{~Pa} \mathrm{~s}=5000 \mathrm{mPa} \mathrm{s}=5000 \mathrm{cP}$ ). These results were in accordance with the macroscopic observations. As a comparison, a viscosity of $38 \mathrm{mPa}$ s was found in the same conditions for [EMIM] $\mathrm{NTf}_{2}$, a value identical to the one reported in the literature $(38.6 \mathrm{mPa}){ }^{43}$

The strong difference of viscosity between the meso or racemate IL and the chiral enantiopure $(2 S, 3 S)$ or $(2 R, 3 R)$

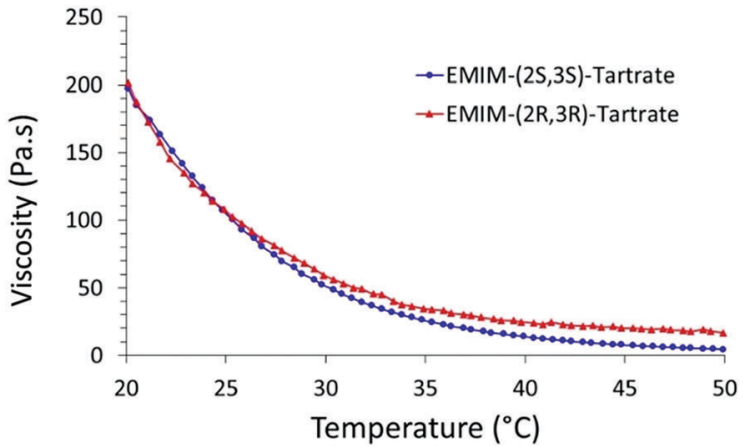

Fig. 5 Temperature dependency of the viscosity of $[E M I M]_{2}(2 S, 3 S)$-Tart $(-)-2$ and $[E M I M]_{2}(2 R, 3 R)-$ Tart $(+)-2$

entities could be related to the difference of hydrogen bond network developed by the tartrate units. The impact of the tartrate stereochemistry on hydrogen bond-driven physicochemical properties is well established, notably regarding tartrate-based crystals. ${ }^{44}$ In the field of ILs, previous studies also focused on the crystalline state. ${ }^{41,42}$ Similar results regarding CILs in the liquid phase remain however, to the best of our knowledge, unprecedented.

In relation with their synthetic application, the temperature dependency of the viscosity was also measured for the two chiral forms (Fig. 5). A quick decrease of the viscosity with temperature was observed, reaching $\approx 100 \mathrm{~Pa} \mathrm{~s}$ at $25{ }^{\circ} \mathrm{C}$ and $\approx 10 \mathrm{~Pa} \mathrm{~s}$ at $50{ }^{\circ} \mathrm{C}$. The variation of the viscosity with temperature follows a power law (Reynold's model) according to the equation $\mu(T)=2544 \exp (-0.129 \times T)$, where $\mu$ is the viscosity (Pa s) and $T$ the temperature $\left({ }^{\circ} \mathrm{C}\right)$. This result showed that those CILs become practical at mild temperature and may be explored as TSILs in organic transformation.

\section{Synthetic application as TSIL}

Finally, in order to exploit the intrinsic basicity of the prepared [EMIM] tartrate salts, their relevance as TSILs was explored to induce a synthetically useful organic transformation. The formation of a high value-added tetraol intermediate in the total synthesis of phytofurans, newly discovered plant lipid metabolites, was selected as a particularly well-suited reaction (Scheme 3$) \cdot{ }^{45}$ According to the previous report, treatment of the $C_{2}$-symmetrical bis-epoxide 3 with 5 equiv. aqueous $\mathrm{KOH}$ at $80{ }^{\circ} \mathrm{C}$ for $2 \mathrm{~h}$ lead to the furanic tetraol 4, isolated as a $c a .80: 20$ (according to ${ }^{13} \mathrm{C}$ NMR) mixture with an unknown diastereoisomer.

This cascade reaction is proposed to be triggered by an initial base-catalysed Payne rearrangement followed by the hydrolysis of the terminal epoxide, in turn inducing an intramolecular 5-exo-tet cyclisation. Due to the key role of hydroxide anion/water as base/ nucleophile, the alternative use of an organic base in non-aqueous conditions is likely to alter the reaction outcome. Yet previous attempts to run this transformation in organic media with a nonnucleophilic base proved unsuccessful, mainly because of the poor solubility of the starting bis-epoxide. The unique properties of ILs as both highly polar and non-protic solvents prompted us to explore their use as alternative reaction media for this transformation. 


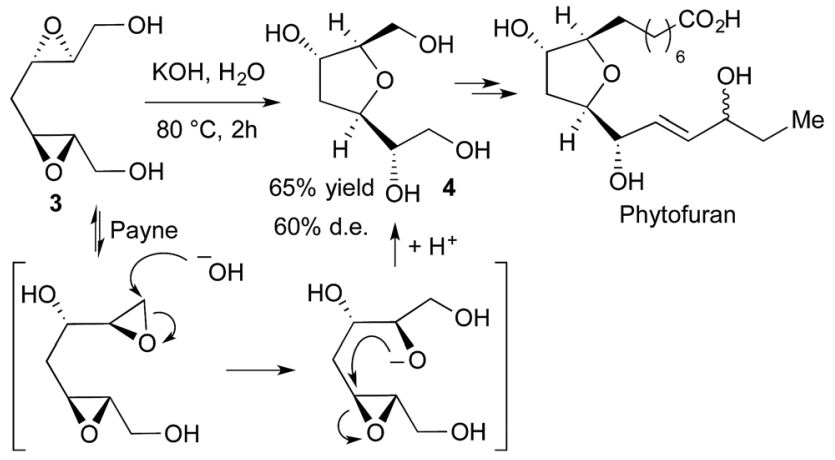

Scheme 3 The model base-induced intramolecular cyclization cascade of $C_{2}$-symmetrical bis-epoxide $\mathbf{3}$ into tetrahydrofuran $\mathbf{4}$ en route to phytofurans.

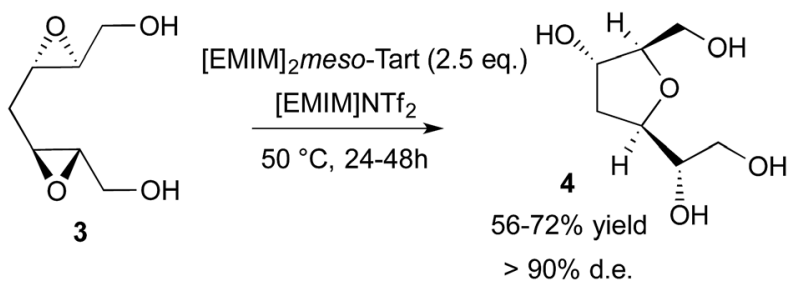

Scheme 4 Cascade reaction forming the furanic tetraol 4 in IL media.
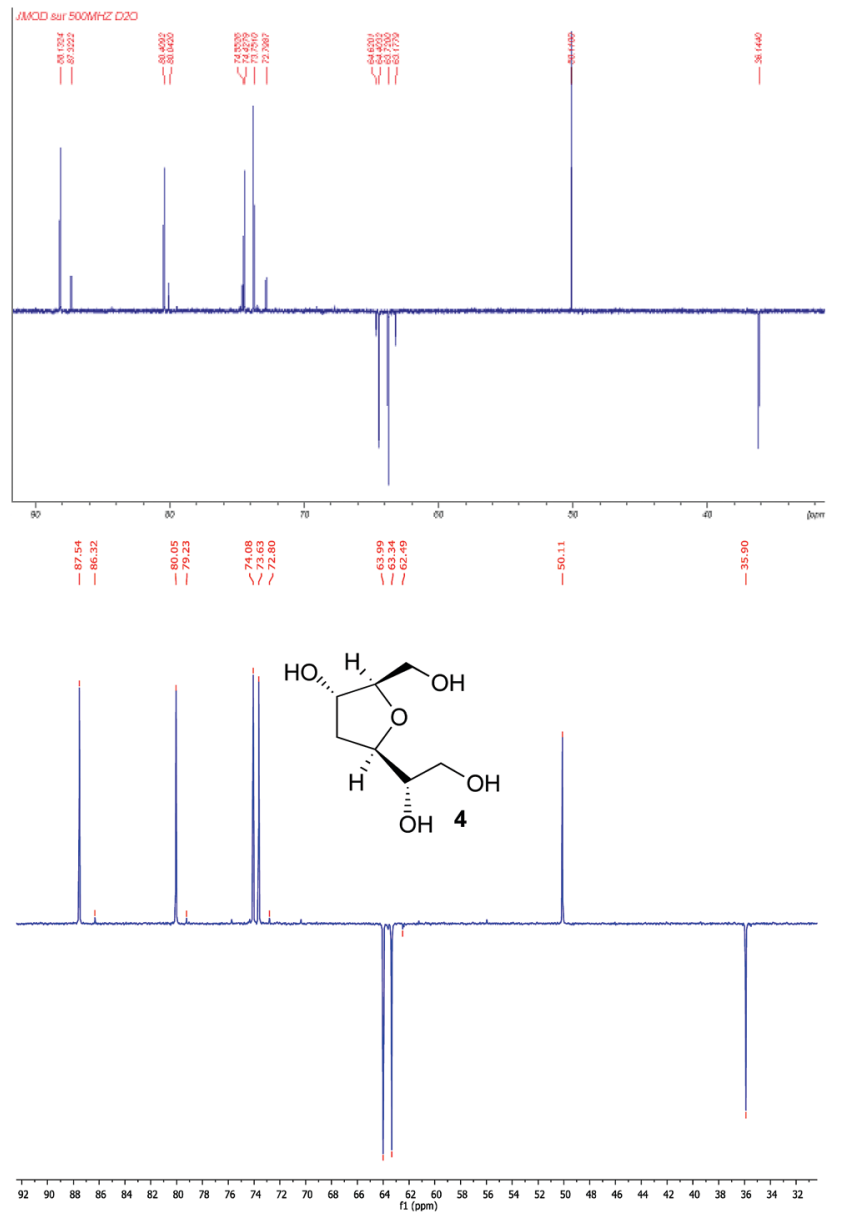

Fig. $6{ }^{13} \mathrm{C}$ NMR spectra of tetrahydrofuran 4 as a ca. $80: 20$ mixture of diastereoisomer (reproduced from ref. 45) and as a > 95:5 mixture of diastereoisomer from the reaction in IL media.
In order to ensure optimal contact between reactants while minimizing the amount of tartrate-based IL used, a reaction system combining 2.5 equiv. of a tartrate salt (for 1 equiv. of the starting bis-epoxide) solubilized in the hydrophobic IL [EMIM] $\mathrm{NTf}_{2}$ was selected (Scheme 4). Since this transformation raised no stereoinduction issues, the less viscous achiral mesotartrate-based IL was selected as a relevant TSIL. Preliminary studies evidenced that, under these alternative conditions, the reaction course was similar to that previously observed in protic media. Gentle heating at $50{ }^{\circ} \mathrm{C}$ for $48 \mathrm{~h}$ led to the clean formation of the expected tetrahydrofuran 4. Gratifyingly, the latter was almost formed as a single diastereoisomer, according to the ${ }^{13} \mathrm{C}$ NMR analysis of the crude mixture. Careful drying of the ILs mixture at $c a \cdot 10^{-3}$ mbar before the reaction appeared key to this stereochemical outcome. Minimizing the amount of water in the reaction media might reduce the formation of the unknown minor diastereoisomer by disfavouring a secondary reaction pathway.

The synthetic utility of this procedure was further assessed by carrying out the reaction at $1 \mathrm{mmol}$ scale. Purification of the crude mixture afforded the expected tetrahydrofuran 4 in 56\% isolated yield as a > 95:5 (according to ${ }^{13} \mathrm{C}$ NMR) mixture of diastereoisomers (Fig. 6). Further optimization showed that the yield could be upgraded to $72 \%$ yield without altering the diastereoisomeric ratio when stopping the reaction after only 24 h. These alternative conditions thus favourably compare, in terms of efficiency and diastereoselectivity, to the original experimental procedure under standard conditions.

\section{Conclusions}

The previously developed general synthetic access to tartratebased CILs was successfully applied to the generation of demanding EMIM derivatives. Thanks to the fine optimization of the treatment of [EMIM] $\mathrm{Br}$ with $\mathrm{AgOH}$, a clean and reliable access to [EMIM] OH water solution was established. Eight different stereoisomeric [EMIM]H-Tart or [EMIM $]_{2}$ Tart were obtained as viscous oils by neutralization of the corresponding acid with appropriate amounts of the aqueous [EMIM $][\mathrm{OH}]$ solution. Full physicochemical characterisation, including thermal phase behaviour, confirmed their proper designation as ionic liquids. Detailed study of their dynamic viscosity further revealed an unprecedented influence of the chirality on their rheological properties, both enantiopure $[\mathrm{EMIM}]_{2}(2 S, 3 S)$ - and $(2 R, 3 R)$-Tart samples displaying a viscosity 40 times higher than that of the racemic or achiral meso forms. Finally, the use of these tartrate salts as basic TSIL was explored in the key step of a recently reported total synthesis of phytofuran metabolites. The reaction in IL media compared favourably in terms of efficiency with the transformation in standard polar protic solvents, the diastereoisomeric excess being notably upgraded from 60 to $90 \%$. This outcome illustrates the relevance of the developed EMIM tartrate derivatives in promoting synthetically useful base-induced organic transformations. 


\section{Experimental}

\section{General information}

NMR spectroscopic data were obtained with Bruker Advance 300. Chemical shifts are quoted in parts per million (ppm) relative to residual solvent peak. $J$ values are given in Hz. Infrared (IR) analysis were recorded with a Nexus-Thermo Nicolet FT-IR using an ATR diamond smart-IR. Mass spectrometry (MS) data were obtained on a ThermoQuest TSQ 7000 spectrometer. Elemental analyses were realized on a Perkin Elmer 2040 series II apparatus. Optical rotations were measured at $20{ }^{\circ} \mathrm{C}$ on a Jasco P 2000 polarimeter. $[\alpha]^{\mathrm{D}}$ values are given in $10^{-1} \mathrm{deg} \mathrm{cm}^{2} \mathrm{~g}^{-1}$. Differential Thermal Analysis (DTA) were run on a Perkin Elmer Diamond TG/DTA apparatus. $T_{\mathrm{d}}$ were determined from the onset of weight loss. Differential Scanning Calorimetry (DSC) plots were recorded with a Netzsch DSC 204 apparatus. $T_{\mathrm{g}}$ were expressed as the inflexion point during the second heating cycle $\left(5{ }^{\circ} \mathrm{C} \mathrm{min}^{-1}\right)$. The dynamic viscosity was measured with a rheometer AR1000 (TA instruments) equipped with a cone-plate configuration (diameter 20 or $40 \mathrm{~mm}$, angle $2^{\circ}$, stainless steel) under air.

\section{Synthetic procedures and characterization of [EMIM] tartrates}

1-Ethyl-3-methylimidazolium bromide ([EMIM]Br). A neat mixture of bromoethane $(2.4 \mathrm{~mL}, 3.2 \mathrm{mmol})$ and 1-methylimidazole $(2.5 \mathrm{~mL}, 3.2 \mathrm{mmol})$ was warm stirred under $\mathrm{Ar}$ atmosphere at $40{ }^{\circ} \mathrm{C}$ for $3 \mathrm{~h}$. After cooling at RT, EtOAc was added to precipitate the product. The salt was filtered, washed with ethyl acetate and dry under vacuum to obtain the crude [EMIM] Br as a white wax (4.33 g, 94\%). ${ }^{1} \mathrm{H}$ NMR $(300 \mathrm{MHz}$, $\left.\mathrm{CD}_{3} \mathrm{OD}\right): \delta$ (ppm) 8.99 (s, 1H), 7.59 (d, $\left.J=24,3 \mathrm{~Hz}, 2 \mathrm{H}\right), 4.29$ (q, $J=7,5 \mathrm{~Hz}, 2 \mathrm{H}), 3.94(\mathrm{~s}, 3 \mathrm{H}), 1.54(\mathrm{t}, J=7,5 \mathrm{~Hz}, 3 \mathrm{H}) .{ }^{13} \mathrm{C}$ NMR (75 MHz, $\left.\mathrm{CD}_{3} \mathrm{OD}\right): \delta$ (ppm) 137.62, 124.97, 123.34, 46.05, 36.50, 15.61 .

Silver hydroxide (AgOH). To a solution of sodium hydroxide $(1.00 \mathrm{~g}, 25 \mathrm{mmol})$ in distilled water $(10 \mathrm{~mL})$ was added silver nitrate $(4.25 \mathrm{~g}, 25 \mathrm{mmol})$. The solution was stirred $10 \mathrm{~min}$ away from light at RT. The resultant mixture was filtered and the solid obtained washed with water. AgOH was dried under vacuum in the dark. The compound was obtained as a fine dark brown powder $(2.81 \mathrm{~g}, 90 \%)$.

1-Ethyl-3-methylimidazolium hydroxide ([EMIM]OH). To a solution of [EMIM] Br $(100 \mathrm{mg}, 0.56 \mathrm{mmol})$ in distilled water $\left(20 \mathrm{~mL} \mathrm{~g}^{-1}\right.$ ) at $0-5{ }^{\circ} \mathrm{C}$ was added freshly prepared $\mathrm{AgOH}$ (1 equiv.). After 5 minutes of stirring at $0-5{ }^{\circ} \mathrm{C}$ and out of direct light, the solution was filtered over $47 \mathrm{~mm}$ hydrophilic propylene $0.2 \mu \mathrm{m}$ membrane filters and washed with distilled water $(10 \mathrm{~mL})$. The resulting [EMIM]OH aqueous solution was used directly for the neutralization of tartaric acid. In order to analyze the product solution, the reaction was also performed in $\mathrm{D}_{2} \mathrm{O}$ according to the same procedure. ${ }^{1} \mathrm{H}$ NMR $\left(300 \mathrm{MHz}, \mathrm{D}_{2} \mathrm{O}\right): \delta(\mathrm{ppm})$ around $8.4(\mathrm{~s}$, highly exchangeable, H2), 7.45 (d, $J=1,8 \mathrm{~Hz}, 1 \mathrm{H}, \mathrm{H} 4), 7.38$ (d, $J=$ $1.8 \mathrm{~Hz}, 1 \mathrm{H}, \mathrm{H} 5$ ), 4.18 (q, $J=7.2 \mathrm{~Hz}, 2 \mathrm{H}, \mathrm{CH}_{2} \mathrm{Me}$ ), 3.85 (s, 3H, NMe), $1.46\left(\mathrm{t}, J=7.2 \mathrm{~Hz}, 3 \mathrm{H}, \mathrm{CH}_{2} \mathrm{Me}\right) .{ }^{13} \mathrm{C}$ NMR $\left(75 \mathrm{MHz}, \mathrm{D}_{2} \mathrm{O}\right): \delta(\mathrm{ppm})$ around 138.00 (C2, non-apparent on 1D spectra), 123.34 (C4), 121.76 (C5), $46.69\left(\mathrm{CH}_{2} \mathrm{Me}\right), 35.50$ (NMe), $14.40\left(\mathrm{CH}_{2} \mathrm{Me}\right)$.
General procedure for the preparation of [EMIM] tartrates. Tartaric acid ( 0.5 or 1 equiv.) was rapidly added to an aqueous solution of [EMIM] OH prepared as indicated above. The resulting mixture was stirred away from light for $2 \mathrm{~h}$ at RT. After evaporation of water on rotary evaporator (water bath temperature $30{ }^{\circ} \mathrm{C}$ ), the residue was dissolved in methanol $(10 \mathrm{~mL})$ and filtered over a $25 \mathrm{~mm}$ Acrodisc ${ }^{\circledR}$ syringe filter equipped with a $0.2 \mu \mathrm{m}$ PTFE membrane to remove the unreacted tartaric acid. The solvent was removed under vacuum and the compound was dried for 2-3 days at RT under $c a .10^{-3}$ bar.

1-Ethyl-3-methylimidazolium hydrogen $(2 R, 3 R)$-tartrate ([EMIM] $(2 R, 3 R)$-HTart), (+)-1. Synthesized according to the general procedure for the preparation of [EMIM] tartrates using [EMIM] Br (1.07 g, $5.6 \mathrm{mmol}), \mathrm{AgOH}(0.71 \mathrm{~g}, 5.6 \mathrm{mmol})$ and $(2 R, 3 R)$-tartaric acid $(0.846 \mathrm{~g}, 5.6 \mathrm{mmol})$. The compound $(+)-1$ was obtained as a clear light yellow viscous oil (1.42 g, 97\%). $[\alpha]_{\mathrm{D}}^{20}+11.6\left(c 1, \mathrm{H}_{2} \mathrm{O}\right) .{ }^{1} \mathrm{H} \mathrm{NMR}\left(300 \mathrm{MHz}, \mathrm{CD}_{3} \mathrm{OD}\right): \delta(\mathrm{ppm}) 9.04$ (s, 1H, H2), 7.66 (d, $J=1.8 \mathrm{~Hz}, 1 \mathrm{H}, \mathrm{H} 4), 7.59$ (d, $J=1.8 \mathrm{~Hz}, 1 \mathrm{H}$, H5), 4.46 (s, 2H, CHOH), 4.29 (q, $J=7,5 \mathrm{~Hz}, 2 \mathrm{H}, \mathrm{CH}_{2} \mathrm{Me}$ ), 3.95 $(\mathrm{s}, 3 \mathrm{H}, \mathrm{NMe}), 1.53\left(\mathrm{t}, J=7,2 \mathrm{~Hz}, 3 \mathrm{H}, \mathrm{CH}_{2} \mathrm{Me}\right) .{ }^{13} \mathrm{C} \mathrm{NMR}(75 \mathrm{MHz}$, $\left.\mathrm{CD}_{3} \mathrm{OD}\right): \delta(\mathrm{ppm}) 176.50(\mathrm{C}=\mathrm{O}), 137.76(\mathrm{C} 2), 124.93$ (C4), 123.22 (C5), $74.03(\mathrm{CHOH}), 45.98\left(\mathrm{CH}_{2} \mathrm{Me}\right), 36.53$ (NMe), 15.67 $\left(\mathrm{CH}_{2} \mathrm{Me}\right)$. ATR-FTIR: $\nu_{\max }\left(\mathrm{cm}^{-1}\right) 3400(\mathrm{O}-\mathrm{H}$, carboxylic acid and hydroxyls), 3152 (C-4, 5-H), 3110 (C-2-H), 2986 (aliph. C-H), 2939 (aliph. C-H), 1732 (C=O, carboxylic acid), 1601 (carboxylate, asym.), 1573 (C=C), 1451 (aliph. C-H), 1389 (aliph. C-H), 1336 (carboxylate, sym.), 1232 (C-OH, carboxylic acid), 1170 (aliph. C-N), 1128 (C-O, hydroxyl), 1083 (C-O, hydroxyl). MS: m/z 111 $\left(\mathrm{IC}+, \mathrm{NH}_{3}\right), m / z 149\left(\mathrm{IC}-, \mathrm{NH}_{3}\right)$. Anal. calc. for $\mathrm{C}_{10} \mathrm{H}_{16} \mathrm{~N}_{2} \mathrm{O}_{6}+1.25$ $\mathrm{H}_{2} \mathrm{O}: \mathrm{C}, 42.48 ; \mathrm{H}, 6.59 ; \mathrm{N}, 9.91 \%$; found: C, 42.43; H, 6.32; N, 10.28\%. DSC: $T_{\mathrm{g}}-19{ }^{\circ} \mathrm{C}$. ATD: $T_{\mathrm{d}} 188{ }^{\circ} \mathrm{C}$.

1-Ethyl-3-methylimidazolium hydrogen (2S,3S)-tartrate ([EMIM]$(2 S, 3 S)$-HTart), (-)-1. Synthesized according to the general procedure for the preparation of [EMIM] tartrates using [EMIM] Br $(1.0 \mathrm{~g}, 5.26 \mathrm{mmol}), \mathrm{AgOH}(0.66 \mathrm{~g}, 5.28 \mathrm{mmol})$ and $(2 S, 3 S)-$ tartaric acid $(0.792 \mathrm{~g}, 5.27 \mathrm{mmol})$. The compound (-)-1 was obtained as a clear light yellow viscous oil (1.34 g, 98\%). It gave analytical data identical to that of its enantiomer except for its optical rotation. $\left.[\alpha]_{\mathrm{D}}^{20}-11.5(c) 1, \mathrm{H}_{2} \mathrm{O}\right)$. Anal. calc. for $\mathrm{C}_{10} \mathrm{H}_{16} \mathrm{~N}_{2} \mathrm{O}_{6}+0.25 \mathrm{H}_{2} \mathrm{O}: \mathrm{C}, 45.37 ; \mathrm{H}, 6.28 ; \mathrm{N}, 10.58 \%$; found: C, 45.69; H, 6.55; N, 11.13\%.

1-Ethyl-3-methylimidazolium hydrogen rac-tartrate ([EMIM]rac-HTart), (rac)-1. Synthesized according to the general procedure for the preparation of [EMIM] tartrates using [EMIM] Br (1.0 $2 \mathrm{~g}, 5.26 \mathrm{mmol}$ ), AgOH (0.64 g, $5.3 \mathrm{mmol}$ ) and racemic tartaric acid $(0.803 \mathrm{~g}, 5.3 \mathrm{mmol})$. The compound ( $r a c)-1$ was obtained as a clear light yellow viscous oil (1.33 g, 96\%). ${ }^{1} \mathrm{H}$ NMR (300 MHz, $\left.\mathrm{CD}_{3} \mathrm{OD}\right): \delta(\mathrm{ppm}) 9.02$ (s, 1H2), 7.64 (d, $J=$ $1.8 \mathrm{~Hz}, 1 \mathrm{H}, \mathrm{H} 4), 7.57$ (d, J=1.8 Hz, 1H, H5), 4.40 (s, 2H, CHOH), 4.27 (q, $J=7,5 \mathrm{~Hz}, 2 \mathrm{H}, \mathrm{CH}_{2} \mathrm{Me}$ ), 3.94 (s, 3H, NMe), 1.52 (t, $J=7$, $5 \mathrm{~Hz}, 3 \mathrm{H}, \mathrm{CH}_{2} \mathrm{Me}$ ). ${ }^{13} \mathrm{C} \mathrm{NMR} 75 \mathrm{MHz}, \mathrm{CD}_{3} \mathrm{OD}: \delta(\mathrm{ppm}) 176.31$ (CO), 137.89 (C2), 124.92 (C4), 123.16 (C5), 74.35 (CHOH), 45.94 $\left(\mathrm{CH}_{2} \mathrm{Me}\right), \quad 36.54 \quad\left(\mathrm{CH}_{3} \mathrm{NMe}\right), 15.69 \quad\left(\mathrm{CH}_{2} \mathrm{Me}\right)$. ATR-FTIR: $\nu_{\max }\left(\mathrm{cm}^{-1}\right) 3385$ (O-H, carboxylic acid and hydroxyls), 3149 (C-4, 5-H), 3105 (C-2-H), 2984 (aliph. C-H), 2957 (aliph. C-H), 1731 (C=O, carboxylic acid), 1607 (carboxylate, asym.), $1573(\mathrm{C}=\mathrm{C})$, 
1451 (aliph. C-H), 1355 (carboxylate, sym.), 1212 (C-OH, carboxylic acid), 1171 (aliph. C-N), 1111 (C-O, hydroxyls), 1094 (C-O, hydroxyls). MS: $m / z 111$ (IC+, $\mathrm{NH}_{3}$ ), m/z 149 (IC-, $\mathrm{NH}_{3}$ ). Anal. calc. for $\mathrm{C}_{10} \mathrm{H}_{16} \mathrm{~N}_{2} \mathrm{O}_{6}+0.25 \mathrm{H}_{2} \mathrm{O}$ : C, 45.37; H, 6.28; $\mathrm{N}, 10.58 \%$; found: $\mathrm{C}, 45.29 ; \mathrm{H}, 6.16 ; \mathrm{N}, 10.76 \%$. DSC: $T_{\mathrm{g}}-19{ }^{\circ} \mathrm{C}$. ATD: $T_{\mathrm{d}} 200{ }^{\circ} \mathrm{C}$.

1-Ethyl-3-methylimidazolium hydrogen meso-tartrate ([EMIM]meso-HTart), meso-1. Synthesized according to the general procedure for the preparation of [EMIM] tartrates using [EMIM]Br (0.99 g, $5.21 \mathrm{mmol})$ AgOH (0.65 g, $5.23 \mathrm{mmol})$ and meso-tartaric acid (0.78 g, $5.3 \mathrm{mmol})$. The compound meso-1 was obtained as a pale yellow wax $(1.20 \mathrm{~g}, 83 \%) .{ }^{1} \mathrm{H}$ NMR (300 MHz, CD $\mathrm{CD}_{3} \mathrm{OD}: \delta(\mathrm{ppm}) 9.04(\mathrm{~s}, 1 \mathrm{H}, \mathrm{H} 2), 7.64(\mathrm{~d}, J=$ $1.8 \mathrm{~Hz}, 1 \mathrm{H}, \mathrm{H} 4), 7.57$ (d, $J=1.8 \mathrm{~Hz}, 1 \mathrm{H}, \mathrm{H} 5), 4.31$ (s, 2H, CHOH), 4.27 (q, $J=7,5 \mathrm{~Hz}, 2 \mathrm{H}, \mathrm{CH}_{2} \mathrm{Me}$ ), 3.94 (s, 3H, NMe), $1.52(\mathrm{t}, J=7$, $5 \mathrm{~Hz}, 3 \mathrm{H}, \mathrm{CH}_{2} \mathrm{Me}$ ). ${ }^{13} \mathrm{C}-\mathrm{NMR}\left(75 \mathrm{MHz}, \mathrm{CD}_{3} \mathrm{OD}\right): \delta$ (ppm) 177.08 (CO), 137.81 (C2), 124.94 (C4), 123.20 (C5), 74.26 (CHOH), 45.96 $\left(\mathrm{CH}_{2} \mathrm{Me}\right), 36.51$ (NMe), $15.67\left(\mathrm{CH}_{2} \mathrm{Me}\right)$. ATR-FTIR: $\nu_{\max }\left(\mathrm{cm}^{-1}\right)$ 3419 (O-H, carboxylic acid and hydroxyls), 3153 (C-4, 5-H), 3112 (C-2-H), 2987 (aliph. C-H), 2946 (aliph. C-H), 1732 (C=O, carboxylic acid), 1608 (carboxylate, asym.), $1574(\mathrm{C}=\mathrm{C}), 1454$ (aliph. C-H), 1343 (carboxylate, sym.), 1222 (C-OH, carboxylic acid), 1170 (aliph. C-N), 1130 (C-O, hydroxyls), 1076 (C-O, hydroxyls). MS: $m / z 111$ (IC+, $\mathrm{NH}_{3}$ ), $m / z 149$ (IC-, $\mathrm{NH}_{3}$ ). Anal. calc. for $\mathrm{C}_{10} \mathrm{H}_{16} \mathrm{~N}_{2} \mathrm{O}_{6}+1.75 \mathrm{H}_{2} \mathrm{O}: \mathrm{C}, 44.04 ; \mathrm{H}, 6.10 ; \mathrm{N}, 10.27 \%$; found: C, 44.25; H, 6.46; N, 10.95\%. DSC: $T_{\mathrm{g}}-22{ }^{\circ} \mathrm{C}$. ATD: $T_{\mathrm{d}} 188^{\circ} \mathrm{C}$.

Bis(1-ethyl-3-methylimidazolium) $(2 R, 3 R)$-tartrate ([EMIM $]_{2^{-}}$ $(2 R, 3 R)$-Tart), $(+)-2$. Synthesized according to the general procedure for the preparation of [EMIM] tartrates using [EMIM] Br (1.03 g, $5.41 \mathrm{mmol})$, AgOH (0.68 g, $5.44 \mathrm{mmol})$ and $(2 R, 3 R)-$ tartaric acid $(0.41 \mathrm{~g}, 2.68 \mathrm{mmol})$. The compound $(+)-2$ was obtained as a clear light yellow viscous oil (0.94 g, 97\%). $[\alpha]_{\mathrm{D}}^{20}+11.1\left(c 1, \mathrm{H}_{2} \mathrm{O}\right) .{ }^{1} \mathrm{H}$ NMR $\left(300 \mathrm{MHz}, \mathrm{CD}_{3} \mathrm{OD}\right): \delta 9.03(\mathrm{~s}$, $2 \mathrm{H}, 2 \times \mathrm{H} 2), 7.64(\mathrm{~d}, J=1.2 \mathrm{~Hz}, 2 \mathrm{H}, 2 \times \mathrm{H} 4), 7.57(\mathrm{~d}, J=1.2 \mathrm{~Hz}$, $2 \mathrm{H}, 2 \times \mathrm{H} 5), 4.32(\mathrm{~s}, 2 \mathrm{H}, \mathrm{CHOH}), 4.27(\mathrm{q}, J=7,2 \mathrm{~Hz}, 4 \mathrm{H}$, $\left.2 \times \mathrm{CH}_{2} \mathrm{Me}\right), 3.94(\mathrm{~s}, 6 \mathrm{H}, 2 \times \mathrm{NMe}), 1.53(\mathrm{t}, J=7,5 \mathrm{~Hz}, 6 \mathrm{H}$, $\left.2 \times \mathrm{CH}_{2} \mathrm{Me}\right) \cdot{ }^{13} \mathrm{C} \mathrm{NMR}\left(75 \mathrm{MHz}, \mathrm{CD}_{3} \mathrm{OD}\right): \delta(\mathrm{ppm}) 179.12(\mathrm{CO})$, 137.91 (C2), 124.91 (C4), 123.20 (C5), 75.21 (CHOH), 45.97 $\left(\mathrm{CH}_{2} \mathrm{Me}\right), 36.44$ (NMe), $15.61\left(\mathrm{CH}_{2} \mathrm{Me}\right)$. ATR-FTIR: $\nu_{\max }\left(\mathrm{cm}^{-1}\right)$ 3398 (O-H, carboxylic acid and hydroxyls), 3149 (C-4, 5-H), 3102 (C-2-H), 2985 (aliph. C-H), 1604 (carboxylate, asym.), 1574 $(\mathrm{C}=\mathrm{C}), 1452$ (aliph. $\mathrm{C}-\mathrm{H}), 1352$ (carboxylate, sym.), 1171 (aliph. C-N), 1119 (C-O, hydroxyls), 1066 (C-O, hydroxyls). MS: m/z 111 $\left(\mathrm{IC}+, \mathrm{NH}_{3}\right), m / z 149\left(\mathrm{IC}-, \mathrm{NH}_{3}\right)$. Anal. calc. for $\mathrm{C}_{16} \mathrm{H}_{26} \mathrm{~N}_{4} 0_{6}+2.5$ $\mathrm{H}_{2} \mathrm{O}: \mathrm{C}, 46.26 ; \mathrm{H}, 7.52 ; \mathrm{N}, 13.49 \%$; found: C, 46.42; H, 7.58; N, $13.77 \%$. DSC: $T_{\mathrm{g}}-54{ }^{\circ} \mathrm{C}$. ATD: $T_{\mathrm{d}} 233{ }^{\circ} \mathrm{C}$.

Bis(1-ethyl-3-methylimidazolium) $(2 S, 3 S)$-tartrate ([EMIM] $]_{2^{-}}$ $(2 S, 3 S)$-Tart), (-)-2. Synthesized according to the general procedure for the preparation of [EMIM] tartrates using [EMIM] Br (1.06 g, $5.58 \mathrm{mmol}), \mathrm{AgOH}(0.697 \mathrm{~g}, 5.58 \mathrm{mmol})$ and $(2 S, 3 S)$-tartaric acid $(0.43 \mathrm{~g}, 2.8 \mathrm{mmol})$. The compound (-)-2 was obtained as a clear light yellow viscous oil (1.03 g, 98\%). It gaves analytical data identical to that of its enantiomer except for its optical rotation. $[\alpha]_{\mathrm{D}}^{20}-11.2$ (c 1, $\left.\mathrm{H}_{2} \mathrm{O}\right)$. Anal. calc. for $\mathrm{C}_{16} \mathrm{H}_{26} \mathrm{~N}_{4} 0_{6}+3.5 \mathrm{H}_{2} \mathrm{O}$ : C, 44.33; $\mathrm{H}, 7.67$; N, 12.93\%; found: C, 44.61; H, 7.49; N, 12.81\%.
Bis(1-ethyl-3-methylimidazolium) rac-tartrate ([EMIM $]_{2}$ racTart), (rac)-2. Synthesized according to the general procedure for the preparation of [EMIM] tartrates using [EMIM] Br $(1.00 \mathrm{~g}$, $5.26 \mathrm{mmol}), \mathrm{AgOH}(0.66 \mathrm{~g}, 5.27 \mathrm{mmol})$ and racemic tartaric acid $(0.39 \mathrm{~g}, 2.63 \mathrm{mmol})$. The compound ( $\mathrm{rac})-2$ was obtained as a clear light yellow viscous oil (0.93 g, 96\%). ${ }^{1} \mathrm{H}$ NMR $(300 \mathrm{MHz}$, $\left.\mathrm{CD}_{3} \mathrm{OD}\right): \delta 9.04(\mathrm{~s}, 2 \mathrm{H}, 2 \times \mathrm{H} 2), 7.64(\mathrm{~d}, J=1.2 \mathrm{~Hz}, 2 \mathrm{H}, 2 \times \mathrm{H} 4)$, $7.57(\mathrm{~d}, J=1.2 \mathrm{~Hz}, 2 \mathrm{H}, 2 \times \mathrm{H} 5), 4.31(\mathrm{~s}, 2 \mathrm{H}, \mathrm{CHOH}), 4.27$ (q, $J=$ 7, $2 \mathrm{~Hz}, 2 \mathrm{H}, \mathrm{CH}_{2} \mathrm{Me}$ ), 3.94 (s, 3H, NMe), 1.53 (t, $J=7,5 \mathrm{~Hz}, 3 \mathrm{H}$, $\mathrm{CH}_{2} \mathrm{Me}$ ). ${ }^{13} \mathrm{C}-\mathrm{NMR}$ (75 MHz, $\left.\mathrm{CD}_{3} \mathrm{OD}\right): \delta$ (ppm) 178.95 (CO), 137.85 (C2), 124.92 (C4), 123.22 (C5), 75.16 (CHOH), 45.95 $\left(\mathrm{CH}_{2} \mathrm{Me}\right), 36.5$ (NMe), $15.70\left(\mathrm{CH}_{2} \mathrm{Me}\right)$. ATR-FTIR: $\nu_{\max }\left(\mathrm{cm}^{-1}\right)$ 3361 (O-H, carboxylic acid and hydroxyls), 3144 (C-4, 5-H), 3085 (C-2-H), 2982 (aliph. C-H), 1606 (carboxylate, asym.), 1573 $(\mathrm{C}=\mathrm{C}), 1452$ (aliph. $\mathrm{C}-\mathrm{H}), 1347$ (carboxylate, sym.), 1173 (aliph. C-N), 1107 (C-O, hydroxyls), 1060 (C-O, hydroxyls). MS: m/z 111 $\left(\mathrm{IC}+, \mathrm{NH}_{3}\right), m / z 149\left(\mathrm{IC}-, \mathrm{NH}_{3}\right)$. Anal. calc. for $\mathrm{C}_{16} \mathrm{H}_{26} \mathrm{~N}_{4} \mathrm{O}_{6}+2.5$ $\mathrm{H}_{2} \mathrm{O}: \mathrm{C}, 46.26 ; \mathrm{H}, 7.52 ; \mathrm{N}, 13.49 \%$; found: C, 46.53; H, 7.72; N, $13.92 \%$. DSC: $T_{\mathrm{g}}-39{ }^{\circ} \mathrm{C}$. ATD: $T_{\mathrm{d}} 240{ }^{\circ} \mathrm{C}$.

Bis(1-ethyl-3-methylimidazolium) meso-tartrate ([EMIM $]_{2}$ meso-Tart), meso-2. Synthesized according to the general procedure for the preparation of [EMIM] tartrates using [EMIM] Br (1.01 g, $5.32 \mathrm{mmol})$, AgOH (0.67 g, $5.34 \mathrm{mmol})$ and meso-tartaric acid $(0.44 \mathrm{~g}, 2.63 \mathrm{mmol})$. The compound meso- 2 was obtained as a clear light yellow viscous oil (0.95 g, 97\%). ${ }^{1} \mathrm{H}$ NMR (300 MHz, $\left.\mathrm{CD}_{3} \mathrm{OD}\right): \delta(\mathrm{ppm}) 9.04(\mathrm{~s}, 2 \mathrm{H}, 2 \times \mathrm{H} 2), 7.63(\mathrm{~d}, J=2.1 \mathrm{~Hz}, 2 \mathrm{H}$, $2 \times \mathrm{H} 4), 7.56(\mathrm{~d}, J=1.8 \mathrm{~Hz}, 2 \mathrm{H}, 2 \times \mathrm{H} 5), 4.27$ (q, $J=7,5 \mathrm{~Hz}$, $2 \mathrm{H}, \mathrm{CH}_{2} \mathrm{Me}$ ), 4.14 (s, 2H, $\left.\mathrm{CHOH}\right), 3.94$ (s, 3H, NMe), 1.53 (t, $J=7$, $5 \mathrm{~Hz}, 3 \mathrm{H}, \mathrm{CH}_{2} \mathrm{Me}$ ). ${ }^{13} \mathrm{C} \mathrm{NMR}\left(75 \mathrm{MHz}, \mathrm{CD}_{3} \mathrm{OD}\right): \delta(\mathrm{ppm}) 177.99$ (CO), 138.02 (C2), 124.87 (C4), 123.17 (C5), 76.0 (CHOH), 45.95 $\left(\mathrm{CH}_{2} \mathrm{Me}\right), 36.5$ (NMe), $15.65\left(\mathrm{CH}_{2} \mathrm{Me}\right)$. ATR-FTIR: $\nu_{\max }\left(\mathrm{cm}^{-1}\right)$ 3374 (O-H, carboxylic acid and hydroxyls), 3145 (C-4, 5-H), 3086 (C-2-H), 2983 (aliph. C-H), 1606 (carboxylate, asym.), $1574(\mathrm{C}=\mathrm{C}), 1452$ (aliph. $\mathrm{C}-\mathrm{H}), 1350$ (carboxylate, sym.), 1173 (aliph. C-N), 1117 (C-O, hydroxyls), 1063 (C-O, hydroxyls). MS: $m / z 111\left(\mathrm{IC}+, \mathrm{NH}_{3}\right), m / z 149\left(\mathrm{IC}-, \mathrm{NH}_{3}\right)$. Anal. calc. for $\mathrm{C}_{16} \mathrm{H}_{26} \mathrm{~N}_{4} \mathrm{O}_{6}+2.5 \mathrm{H}_{2} \mathrm{O}: \mathrm{C}, 46.26 ; \mathrm{H}, 7.52 ; \mathrm{N}, 13.49 \%$; found: C, 46.42; H, 7.58; N, 13.77\%. DSC $T_{\mathrm{g}}-53{ }^{\circ} \mathrm{C}$. ATD $T_{\mathrm{d}} 217{ }^{\circ} \mathrm{C}$.

\section{Rheology}

Before each measurement, the IL was dried for $48 \mathrm{~h}$ under a vacuum of $3 \times 10^{-3}$ mbar, placed rapidly into the geometry gap (diameter $20 \mathrm{~mm}, 2^{\circ}$ ) and measured immediately after. For measurements at fixed temperature $\left(20{ }^{\circ} \mathrm{C}\right)$, a logarithmic increase of the shear rate from 0.3 to $10 \mathrm{~s}^{-1}$ has been applied to the sample with a total duration of $5 \mathrm{~min}$. A second measurement starting $5 \mathrm{~min}$ after the end of the first measurement provided the same curves and viscosity values for all the samples, indicating that the viscosity was not affected by hydration at the early stage of the measurement. The viscosity was found to be independent of the shear rate applied (Newtonian behavior) (Fig. SI-1, ESI $\dagger$ ). The viscosity values were extracted for a shear rate $=1 \mathrm{~s}^{-1}$. Observed values were: $192 \mathrm{~Pa} \mathrm{~s}$ ([EMIM $]_{2}(2 R, 3 R)$-Tart), $199 \mathrm{~Pa} \mathrm{~s}$ ([EMIM $]_{2}(2 S, 3 S)$-Tart), $6 \mathrm{~Pa} \mathrm{~s}$ ([EMIM $]_{2}$ rac-Tart) and $5 \mathrm{~Pa} \mathrm{~s}\left([\mathrm{EMIM}]_{2}\right.$ meso-Tart). For the measurements in function of temperature, a linear temperature ramp 
has been applied from $20{ }^{\circ} \mathrm{C}$ to $50{ }^{\circ} \mathrm{C}$ with a total duration of $5 \mathrm{~min}\left(6^{\circ} \mathrm{C} \mathrm{min}^{-1}\right)$. The data in Fig. 5 show that the variation of the viscosity with temperature follows a power law (Reynold's model) according to the equation $\mu(T)=2544 \exp (-0.129 \times T)$, where $\mu$ is the viscosity (Pa s) and $T$ the temperature $\left({ }^{\circ} \mathrm{C}\right.$ ). For comparison, the viscosity of $\operatorname{EMIM}(\mathrm{NTf})_{2}$ at $20{ }^{\circ} \mathrm{C}$ was measured in the same conditions of drying and measurement, except the geometry (diameter $40 \mathrm{~mm}, 2^{\circ}$ ).

\section{Use of [EMIM] tartrates as TSIL in the model intramolecular cyclization cascade}

General procedure for the reaction in IL. To a mixture of $[\mathrm{EMIM}]_{2}$ Tart (2.5 equiv.) and [EMIM] $\mathrm{NTf}_{2}(80 \mathrm{w} \%)$ dried at ca. $10^{-3}$ mbar for $48 \mathrm{~h}$, was added the bis-epoxydiol 3 (1 equiv.). The reaction was stirred at $50{ }^{\circ} \mathrm{C}$. After cooling to RT, the crude was purified by flash chromatography eluted with DCM/MeOH $(90: 10$ to $85: 15)$ to afford the expected tetrahydrofuran 4 .

Tetrahydrofuran 4. Obtained according to the general procedure for the reaction in IL using bis-epoxydiol $3(170 \mathrm{mg}$, $1.10 \mathrm{mmol}$ ), [EMIM] ${ }_{2}$ meso-Tart (1.02 g, $2.75 \mathrm{mmol}$ ), [EMIM] $\mathrm{NTf}_{2}$ $(800 \mathrm{mg})$ for $48 \mathrm{~h}$. Purification gave the expected product $4(110 \mathrm{mg}$, $56 \%$ ) in $>90 \%$ d.e. (according to ${ }^{13} \mathrm{C} \mathrm{NMR}$ ).

\section{Conflicts of interest}

There are no conflicts to declare.

\section{Acknowledgements}

The "Institut de Chimie de Toulouse" (ICT) is thanked for physicochemical analyses. In particular, Corinne Routaboul is acknowledged for IR spectroscopy. The authors would also like to thank the University of Montpellier for a fellowship to CC.

\section{Notes and references}

1 C. Baudequin, D. Brégeon, J. Levillain, F. Guillen, J.-C. Plaquevent and A.-C. Gaumont, Tetrahedron: Asymmetry, 2005, 16, 3921-3945; J. Ding and D. Armstrong, Chirality, 2005, 17, 281-292; K. Bica and P. Gaertner, Eur. J. Org. Chem., 2008, 3235-3250; A. Winkel, P. V. G. Reddy and R. Wilhelm, Synthesis, 2008, 999-1016; T. Payagala and D. W. Armstrong, Chirality, 2012, 24, 17-53.

2 E. Husanu, V. Cappello, C. S. Pomelli, J. David, M. Gemmi and C. Chiappe, $R S C A d v$., 2017, 7, 1154-1160; H. Lu, W. Xu, Z. Song, S. Zhang, L. Qiu, X. Wang, G. Zhang, J. Hu and G. Lv, Opt. Lett., 2014, 39, 6795.

3 D. Wu, P. Cai, X. Zhao, Y. Kong and Y. Pan, J. Sep. Sci., 2018, 41, 373-384.

4 M. Ferrari Bach, C. Herzer Griebeler, C. Gross Jacoby and P. H. Schneider, Eur. J. Org. Chem., 2017, 6997-7004; P. Goodrich, H. Q. Nimal Gunaratne, L. Hall, Y. Wang, L. Jin, M. J. Muldoon, A. P. C. Ribeiro, A. J. L. Pombeiro, V. I. Pârvulescu, P. Davey and C. Hardacre, Dalton Trans., 2017, 46, 1704-1713.
5 J. Hulsbosch, D. E. De Vos, K. Binnemans and R. Ameloot, ACS Sustainable Chem. Eng., 2016, 4, 2917-2931.

6 Y. Fukaya, Y. Iizuka, K. Sekikawa and H. Ohno, Green Chem., 2007, 9, 1155-1157.

7 For the use of tartaric acid as a synthetic precursor of pyrrolidinium CILs, see: M. Bonanni, G. Soldaini, C. Faggi, A. Goti and F. Cardona, Synlett, 2009, 747-750.

8 S. Gore, S. Baskaran and B. Koenig, Green Chem., 2011, 13, 1009-1013; S. Gore, S. Baskaran and B. Koenig, Org. Lett., 2012, 14, 4568-4571; S. Gore, K. Chinthapally, S. Baskaran and B. Koenig, Chem. Commun., 2013, 49, 5052-5054.

9 C. R. Allen, P. L. Richard, A. J. Ward, L. G. A. van de Water, A. F. Masters and T. Maschmeyer, Tetrahedron Lett., 2006, 47, 7367-7370.

10 G. Ou, M. Zhu, J. She and Y. Yuan, Chem. Commun., 2006, 4626-4628.

11 S. Bose, A. B. Wijeratne, A. Thite, G. A. Kraus, D. W. Armstrong and J. W. Petrich, J. Phys. Chem. B, 2009, 113, 10825-10829.

12 S. Zhang, Y. Huang, H. Jing, W. Yao and P. Yan, Green Chem., 2009, 11, 935-938.

13 E. Kowsari and M. R. Ghezelbash, Mater. Lett., 2012, 68, 17-20.

14 E. Kowsari and A. H. Karimzadeh, Mater. Lett., 2012, 78, 150-153.

15 S. Sekar, M. Surianarayanan, V. Ranganathan, D. R. MacFarlane and A. B. Mandal, Environ. Sci. Technol., 2012, 46, 4902-4908.

16 V. Zgonnik, C. Zedde, Y. Génisson, M.-R. Mazières and J.-C. Plaquevent, Chem. Commun., 2012, 48, 3185-3187.

17 T. Fan, C. Chen, T. Fan, F. Liu and Q. Peng, J. Hazard. Mater., 2015, 297, 340-346.

18 F. Keramatnia, A. Jouyban, H. Valizadeh, A. Delazar and A. Shayanfar, Fluid Phase Equilib., 2016, 425, 108-113.

19 N. Ferlin, M. Courty, S. Gatard, M. Spulak, B. Quilty, I. Beadham, M. Ghavre, A. Haiss, K. Kuemmerer, N. Gathergood and S. Bouquillon, Tetrahedron, 2013, 69, 6150-6161; S. Hayouni, A. Robert, N. Ferlin, H. Amri and S. Bouquillon, RSC Adv., 2016, 6, 113583-113595.

20 S. Hayouni, N. Ferlin and S. Bouquillon, Mol. Catal., 2017, 437, 121-129.

21 P. Goodrich, H. Q. Nimal Gunaratne, L. Hall, Y. Wang, L. Jin, M. J. Muldoon, A. P. C. Ribeiro, A. J. L. Pombeiro, V. I. Pârvulescu, P. Davey and C. Hardacre, Dalton Trans., 2017, 46, 1704-1713.

22 V. Raghavan and P. L. Polavarapu, J. Phys. Chem. B, 2017, 121, 1629-1639. For the early preparation of similar protic CIL from tartaric acid and their use in cyanosilylation of aldehyde, see: L. Mei, Z. J. Hai, Y. Hao, S. Jie and H. K. Liang, Open Catal. J., 2010, 3, 87-91.

23 T. P. Thuy Pham, C.-W. Cho and Y.-S. Yun, Water Res., 2010, 44, 352-372.

24 H. Liu, J. Wu, X. Zhang, Y. Xia, Y. Li and S. Du, Sci. Total Environ, 2017, 595, 819-827; H. Liu, X. Zhang, Y. Dong, C. Chen, S. Zhu and X. Ma, Aquat. Toxicol., 2015, 169, 179-187. 
25 Two proline-derived tartrate salts were also reported as part of a CIL library without being described, see: L. Zhang, S. Luo, X. Mi, S. Liu, Y. Qiao, H. Xu and J.-P. Cheng, Org. Biomol. Chem., 2008, 6, 567-576.

26 For an early example of preparation of ILs by neutralization of an ammonium hydroxide salt with sulfonic acid, see: J. Golding, S. Forsyth, D. R. MacFarlane, M. Forsyth and G. B. Deacon, Green Chem., 2002, 4, 223-229.

27 K. Fukumoto, M. Yoshizawa and H. Ohno, J. Am. Chem. Soc., 2005, 127, 2398-2399.

28 B. C. Ranu and S. Banerjee, Org. Lett., 2005, 7, 3049-3052.

29 J. Pernak, N. Borucka, F. Walkiewicz, B. Markiewicz, P. Fochtman, S. Stolte, S. Steudte and P. Stepnowski, Green Chem., 2011, 13, 2901-2910.

30 O. Hollóczki and L. Nyulászi, Org. Biomol. Chem., 2011, 9, 2634-2640.

31 A. K. L. Yuen, A. F. Masters and T. Maschmeyer, Catal. Today, 2013, 200, 9-16.

32 E. Alcalde, I. Dinarès, A. Ibáñez and N. Mesquida, Chem. Commun., 2011, 47, 3266-3668.

33 Y. Peng, G. Li, J. Li and S. Yu, Tetrahedron Lett., 2009, 50, 4286-4288.

34 For selected examples of the use of [BMIM] $\mathrm{OH}$ as catalyst, see: J.-M. Xu, B.-K. Liu, W.-B. Wu, C. Qian, Q. Wu and X.-F. Lin, J. Org. Chem., 2006, 71, 3991-3993; B. C. Ranu and R. Jana, Eur. J. Org. Chem., 2006, 3767-3770; L. Yang, L.-W. Xu, W. Zhou, L. Li and C.-G. Xia, Tetrahedron Lett., 2006, 47, 7723-7726; B. C. Ranu, R. Jana and S. Sowmiah, J. Org. Chem., 2007, 72, 3152-3154; I. Yavari and E. Kowsari, Synlett, 2008, 897-899; Y. P. Patil, P. J. Tambade, K. M. Deshmukh and B. M. Bhanage, Catal. Today, 2009, 148, 355-360.

35 A. Rouch, T. Castellan, I. Fabing, N. Saffon, J. Rodriguez, T. Constantieux, J.-C. Plaquevent and Y. Génisson, RSC Adv., 2013, 3, 413-426.

36 L. Huang, Y.-T. Chen, Y.-X. Li and L.-S. Yu, Appl. Spectrosc., 2016, 70, 1649-1654.
37 L. Huang, L.-S. Yu, Y.-T. Chen and Y.-X. Li, LC.GC Eur., 2016, 29, 618-623.

38 S. Himmler, A. König and P. Wasserscheid, Green Chem., 2007, 9, 935-942.

39 M. T. Clough, K. Geyer, P. A. Hunt, S. Son, U. Vagt and T. Welton, Green Chem., 2015, 17, 231-243.

40 (a) J. C. Lassegues, J. Grondin, D. Cavagnat and P. Johansson, J. Phys. Chem. A, 2009, 113, 6419-6421; (b) Y. Gao, L. Zhang, Y. Wang and H. Li, J. Phys. Chem. B, 2010, 114, 2828-2833; (c) S. A. Katsyuba, M. V. Vener, E. E. Zvereva, Z. F. Fei, R. Scopelliti, G. Laurenczy, N. Yan, E. Paunescu and P. J. Dyson, J. Phys. Chem. B, 2013, 117, 9094-9105; (d) For a comprehensive review on the IR analyses of ILs, see: V. H. Paschoal, L. F. O. Faria and M. C. C. Ribeiro, Chem. Rev., 2017, 117, 7053-7112.

41 N. Ríos-Lombardía, E. Busto, V. Gotor-Fernández, V. Gotor, R. Porcar, E. García-Verdugo, S. V. Luis, I. Alfonso, S. GarcíaGranda and A. Menéndez-Velázquez, Chem. - Eur. J., 2010, 16, 836-847. For a related study on the corresponding triazolium salts, see: R. Porcar, N. Ríos-Lombardía, E. Busto, V. GotorFernández, J. Montejo-Bernardo, S. García-Granda, S. V. Luis, V. Gotor, I. Alfonso and E. García-Verdugo, Chem. - Eur. J., 2013, 19, 892-904.

42 For a recent report regarding cationic sandwich ruthenium complexes-based CILs, see: T. Higashi, T. Ueda and T. Mochida, Phys. Chem. Chem. Phys., 2016, 18, 10041-10048.

43 A. P. Fröba, H. Kremer and A. Leipertz, J. Phys. Chem. B, 2008, 112, 12420-12430. For a more complete database on viscosity of ionic liquids, see: K. Paduszyński and U. Domańska, J. Chem. Inf. Model., 2014, 54, 1311-1324.

44 H. H.-M. Yeung, M. Kosa, M. Parrinello and A. K. Cheetham, Cryst. Growth Des., 2013, 13, 3705-3715; K. Ohno, H. Tanuma, Y. Kusano, S. Kaizaki, A. Nagasawa and T. Fujihara, Dalton Trans., 2017, 46, 7612-7618.

45 C. Cuyamendous, K. S. Leung, T. Durand, J. C.-Y. Lee, C. Oger and J.-M. Galano, Chem. Commun., 2015, 51, 15696-15699. 